\title{
Role of Ginkgo biloba Extract, Against Isoproterenol Induced Cardiac Toxicity in Rats
}

\author{
Narendra Singh Badore ${ }^{1 *}$, Prabhat Kumar Das², Sujit Pillai ${ }^{3}$, Akshita Thakur ${ }^{1}$ \\ 1'Department of Pharmacognosy, GRY Institute of Pharmacy, Borawan, Khargone, Madhya Pradesh, INDIA. \\ 2Department of Pharmacology, GRY Institute of Pharmacy, Borawan, Khargone, Madhya Pradesh, INDIA. \\ ${ }^{3}$ Department of Pharmaceutical chemistry, GRY Institute of Pharmacy, Borawan, Khargone, Madhya Pradesh, INDIA.
}

\begin{abstract}
Objective: Ginkgo biloba is a potent antioxidant dietary source for human health. Oxidative stress through generation of free radicals damages the myocardium in different experimental condition. The present research was designed to evaluate the cardio protective role of chronic oral administration of Ginkgo biloba leaf extract against Isoproterenol induced myocardial injury. Material and methods: Male Wistar albino rats were randomly divided into five groups $(n=6)$ and treated as per treatment protocol with three different dose of Ginkgo biloba extract $(125,250$, and $500 \mathrm{mg} / \mathrm{kg}$ b.w.) orally for thirty days. At the end of the treatment all the rats (except control rats) were administered with Isoproterenol $(85 \mathrm{mg} / \mathrm{kg})$ two consecutive days and subjected to biochemical and histopathological estimation. Results: Isoproterenol (group II) induced the oxidative myocardial damage via alteration in the endogenous antioxidant enzymes and myocardial marker enzymes. Ginkgo biloba extract in all three dose (group III, IV and V) shows protective mechanism via decreasing thiobarbituric acid reactive substance (TBARS) and enhancing the endogenous antioxidant enzymes (reduced glutathione (GSH), superoxide dismutase (SOD) and catalase). The extract effect was compared with the reference standard $\alpha$-tocopherol which also offered similar protection in biochemical and histopathological changes. Conclusion: Thus, the study shows that Ginkgo biloba extract exhibits significant antioxidant activity and protect the heart from free radical mediated toxicity of Isoproterenol.
\end{abstract}

Key words: Antioxidant, Cardiotoxicity, Ginkgo biloba, Isoproterenol, Wistar albino rats, $\alpha$-tochopherol.

\section{INTRODUCTION}

Myocardial infarction is the acute condition of necrosis of the myocardium that occurs as a result of imbalance between coronary blood supply and myocardial demand. ${ }^{1}$ Oxidative stress resulting from increased production of free radicals is associated with decreased levels of antioxidants in the myocardium and plays a major role in cardiovascular diseases. ${ }^{2}$ Damage to the myocardial cells arises due to the generation of toxic reactive oxygen species such as superoxide radical, hydrogen peroxide and hydroxyl radical. ${ }^{3}$ Isoproterenol (ISO) is an adrenergic agonist and acute administration of ISO in experimental animals causes necrosis to heart muscle. ${ }^{4}$ ISO damages the myocardial via calcium accumulation in cytosolic membrane, generation of reactive oxygen species and procogulant activity. ${ }^{5}$ ISO causes the patchy pathological changes in the myocardial tissue, which is almost clinically relevant to myocardial infarction of ischemic heart disease. $^{6}$

Phytopharmaceutical are gaining importance in allopathic as well as traditional medicine owing to their non-addictive and less toxic nature. Drugs to enhance the endogenous antioxidant enzymes to protect the heart from stress have been paid more attention. Natural antioxidants play a major role to
Submission Date: 17-07-2017; Revision Date: 27-08-2017; Accepted Date: 31-10-2017

DOI: 10.5530/ijper.51.4s.100 Correspondence:

Mr. Narendra S Badore, Asst. Professor, Department of Pharmacognosy, GRY Institute of Pharmacy, Vidya Vihar, Borawan, Khargone, Madhya Pradesh, INDIA. Phone no.: 07773855009 E-mail: kumar_prabhat3027@ yahoo.com

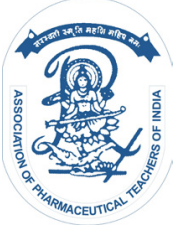

www.ijper.org 
reduce the oxidative stress by scavenging the excess free radicals. ${ }^{7}$ Administration of antioxidants during ischemic reperfusion injury ameliorates the severity of IRI through augmentation of endogenous antioxidants, which might be a promising loom to treat heart disease. ${ }^{8,9}$

Several natural products have been reported to have protective roles against ISO-induced MI in rats. Ginkgo biloba L. (Family-Ginkgoaceae) is the one of oldest existing seed plants, also known as "living fossils." It contains Flavonol and flavone glycosides, Ginkgolides, Diterpen lactones, ascorbic acid, Sesquiterpenes, Catechin and Iron-based superoxide dismutase. ${ }^{10}$ Ginkgo biloba has been reported to have memory enhancer, antidepressant, antimicrobial, hepatoprotective, anticoagulant, anti-inflammatory, cytotoxic, anti-stress, anti-ulcer, anti-tubercular and anti-aging properties. ${ }^{11-22}$ Gink.go biloba also known for its antioxidant activity and effective scavenger of oxidative radicals. ${ }^{23}$ Ginkgo biloba are popular for their nutritional and medicinal values but have no studies conducted in direction of protective role of ginkgo biloba extract against ISO induced Cardiotoxicity may be via antioxidant system. Hence, the present study was undertaken to find out the cardio protective potency of methanolic extract of Ginkgo biloba leaves.

\section{MATEIALS AND METHODS}

\section{Drugs and Chemicals}

Leaves of Ginkgo biloba was collected from Darjeeling, West Bengal, India, and were authenticated by Dr. S. K. Mahajan M Sc, PhD, department of botany, Govt. P. G. Collage, Khargone, M.P, India. All chemicals were of analytical grade purchased from sigma chemicals, USA.

\section{Extract preparation}

Dried leaves of Ginkgo biloba were coarsely powdered and $1 \mathrm{~kg}$ of this powered plant material was extracted with the help of the soxhlet apparatus using methanol as a solvent. The solvent from the methanolic extract was removed under vacuum distillation; dried material was kept in a desiccators. A suspension of the leaves in 5\% Tween 80 (Vehicle) was made daily.

\section{Physicochemical Analysis}

For physicochemical analysis fresh plant material was collected and shade dried.

Physical constants were determined following Indian Pharmacopoeia. It includes ash value, extractive value and moisture content.

\section{Preliminary Phytochemical analysis}

MEGB was analyzed for the various classes of phytoconstituents such as flavonoids, phenolic acids, anthocyanins, quinones, alkaloids, tannins, and saponins using standard phytochemical methods. Phytochemical tests were carried out following Shah and Quadry and Kokate. ${ }^{24-25}$

\section{Experimental animals}

Male Wistar albino rats of body weight 150-200 g were obtained from the Institute Animal House. The rats were acclimatized in the department animal house at an ambient temperature of $25^{\circ} \mathrm{C}$, under a $12 \mathrm{~h}$ dark $-12 \mathrm{~h}$ light, cycle, for the whole period of the study. The animals were fed with a standard pellet diet and water ad libitum. The experiment was carried out according to the guidelines of the Committee for the Purpose of Control and Supervision of Experimental on Animals, New Delhi, India and the research protocol was approved by the Institute animal ethical committee (1151/ac/07/CPCSEA).

\section{Experimental Protocol}

The rats were divided into 5 groups (6 in each group) and fed with the suspension of Ginkgo biloba leaves extract of three doses $(125 \mathrm{mg} / \mathrm{kg}, 250 \mathrm{mg} / \mathrm{kg}$ and $500 \mathrm{mg} / \mathrm{kg}$ ) by oral gavages once a day for 4 weeks ( 6 days/week). At the end of the treatment period rats from all groups except control group were administered Isoproterenol (ISO) $85 \mathrm{mg} / \mathrm{kg}$ i.p., for two consecutive days to induce myocardial injury. Rats were pretreated with $\alpha$-tocopherol (60 mg/ $\mathrm{kg}$ body weight, orally) for a period of 28 days and in addition, received isoproterenol $85 \mathrm{mg} / \mathrm{kg}$ body weight) on the 29 and 30 day at an interval of $24 \mathrm{~h}$. After 48 hours of the first dose of ISO the rats were sacrificed, hearts and blood samples were collected and immediately frozen in liquid nitrogen for biochemical estimation. ${ }^{26}$

\section{Treatment protocol}

The groups studied were:

Group I: Control, Vehicle + saline injected rats

Group II: Vehicle + ISO treated rats $(85 \mathrm{mg} / \mathrm{kg})$

Group III: $125 \mathrm{mg} / \mathrm{kg}$ of MEGB + ISO treated rats (85 mg/kg)

Group IV: $250 \mathrm{mg} / \mathrm{kg}$ of MEGB + ISO treated rats (85 mg/kg)

Group V: $500 \mathrm{mg} / \mathrm{kg}$ of MEGB + ISO treated rats $(85 \mathrm{mg} / \mathrm{kg}$ )

Group VI: $\alpha$-tocopherol (60 mg/kg body weight, orally) 


\section{Estimation of biochemical parameters}

The following biochemical parameters were studied in the heart homogenate.

\section{Myocardial thiobarbituric acid reactive substances}

TBARS levels in the myocardium were determined by the method described by Ohkawa et al (1997). ${ }^{25}$ Hearts were homogenized with $10 \mathrm{ml}$ of Trichloroacetic acid (TCA). $0.2 \mathrm{ml}$ of whole homogenate was taken to which $0.2 \mathrm{ml}$ of $8.1 \%$ Sodium lauryl sulfate, $1.5 \mathrm{ml}$ of $20 \%$ acetic acid and $1.5 \mathrm{ml}$ of $0.8 \%$ TBA were added. Volume was made up to $4 \mathrm{ml}$ with double distilled water. It was heated at $95^{\circ} \mathrm{C}$ for $60 \mathrm{~min}$. After cooling, $1 \mathrm{ml}$ of double distilled water and $5 \mathrm{ml}$ of butanol: pyridine mixture was added and centrifuged at $4000 \mathrm{rpm}$ for $10 \mathrm{~min}$ in a cold centrifuge. The organic layer was separated and absorbance was observed at $532 \mathrm{~nm}$ in a spectrophotometer.

\section{Myocardial reduced glutathione}

Myocardial GSH was estimated by the method of Ellman et al, (1959). ${ }^{27}$ The reaction mixture contained $0.1 \mathrm{~mL}$ of supernatant, $2.0 \mathrm{ml}$ of $0.3 \mathrm{M}$ phosphate buffer (pH- 8.4), $0.4 \mathrm{ml}$ of double-distilled water and $0.5 \mathrm{ml}$ of 5, 5 dithiobis 2 -nitrobenzoic acid. The reaction mixture was incubated for $10 \mathrm{~min}$ and the absorbance was measured at $412 \mathrm{~nm}$. Data are expressed as mole per gram wet weight.

\section{Superoxide dismutase}

SOD levels in the hearts were determined by McCord and Firdovich method (1969) and modified by Kakkar et al. ${ }^{28}$ A sample $(100 \mu \mathrm{l})$ was added to sodium pyrophosphate buffer ( $\mathrm{pH}-8.3$ ), followed by addition of $0.1 \mathrm{~mL}$ of $186 \mathrm{M}$ phenazine methosulfate, $0.3 \mathrm{~mL}$ of $300 \mathrm{mM}$ nitroblue tetrazolium and $0.2 \mathrm{ml}$ of $780 \mathrm{MNADH}$. The reaction mixture was incubated for 90 second at $30{ }^{\circ} \mathrm{C}$ and the reaction was stopped by adding $1.0 \mathrm{ml}$ of acetic acid, $4.0 \mathrm{ml}$ of n-butanol was then added and centrifuged at $3000 \mathrm{~g}$ for $10 \mathrm{~min}$. The absorbance of the organic layer was measured at $560 \mathrm{~nm}$. Data are expressed as units per mg protein.

\section{Estimation of Catalase}

Catalase level was estimated by the method described by Aebi et al. ${ }^{29}$ Sample $(50 \mu \mathrm{l})$ was added to a $3.0 \mathrm{ml}$ cuvette that contained $1.95 \mathrm{ml}$ of $50 \mathrm{mM}$ phosphate buffer (pH 7.0). Then $1.0 \mathrm{ml}$ of $30 \mathrm{mM}$ hydrogen peroxide was added and changes in absorbance were followed for $30 \mathrm{~s}$ at $240 \mathrm{~nm}$ at an interval of $15 \mathrm{~s}$. Catalase levels are expressed as units per $\mathrm{mg}$ protein.

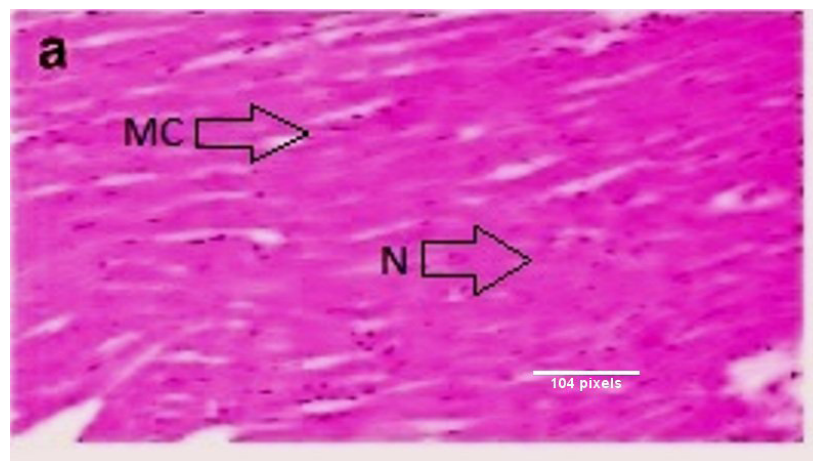

Figure 1: Vehicle-received rat heart shows the normal cytoarchitecture of the myocardium. $M C=$ Myocardial cells, $N=$ nucleus.

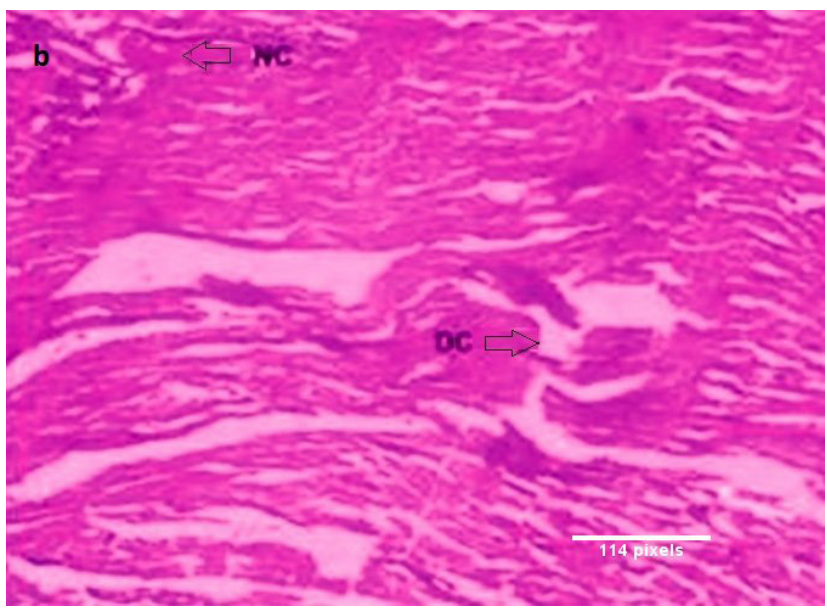

Figure 2: ISO-treated rat heart shows the necrotic changes in myocardial tissue. $\mathrm{NC}=$ Necrotic changes, $\mathrm{DC}=$ Degenerative changes.

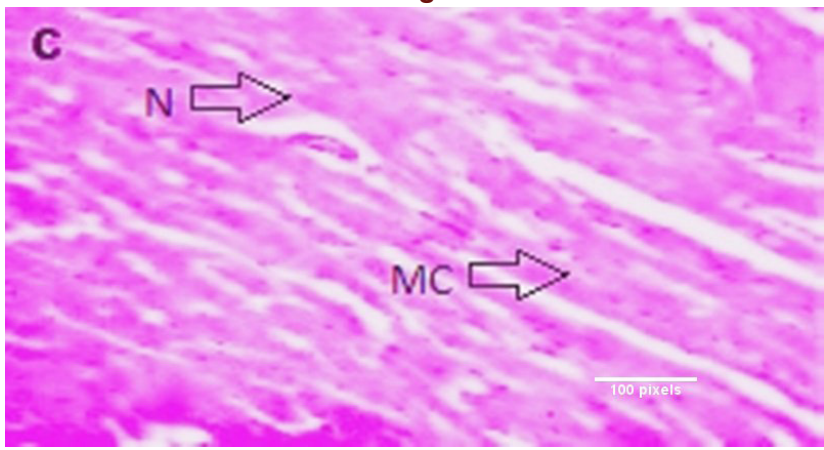

Figure 3: MEGB (125 mg/kg)-treated rat heart shows regenerative changes in myocardial tissue. $M C=$ Myocardial cells, $\mathrm{N}=$ Nucleus.

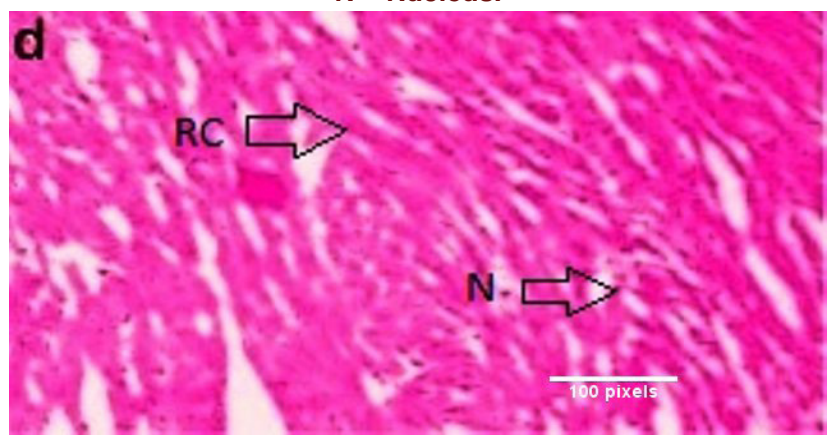

Figure 4: MEGB $(250 \mathrm{mg} / \mathrm{kg})$-treated rat heart shows regenerative changes in myocardial tissue. $\mathrm{RC}=$ Regenerative changes, $\mathbf{N}=$ Nucleus. 


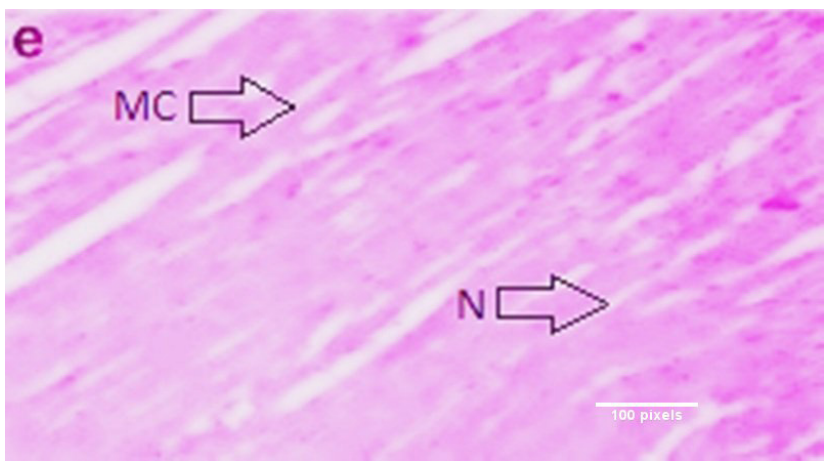

Figure 5: MEGB $(500 \mathrm{mg} / \mathrm{kg})$-treated rat heart shows normal cyto architecture of myocardium. MC= Myocardial cells, $\mathbf{N}=$ Nucleus.

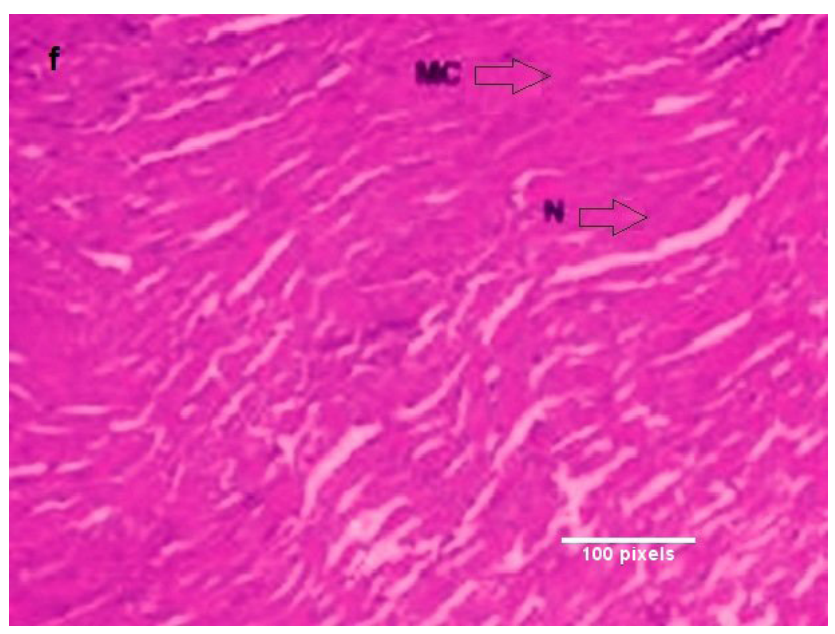

Figure 6: a-tocopherol (60 mg/kg)-treated rat heart shows normal cyto-architecture of myocardium. $\mathrm{MC}=$ Myocardial cells, $\mathbf{N}=$ Nucleus

\section{Estimation of Protein}

Protein estimation for the tissue samples were done by the method of Bradford ${ }^{30}$ Sample $(2 \mu \mathrm{l})$ was made up to $20 \mu \mathrm{l}$ with double-distilled water, $50 \mu \mathrm{l}$ of $0.1 \mathrm{~N} \mathrm{NaOH}$ and $1 \mathrm{~mL}$ of Bradford reagent were added, vortexed and kept for $10 \mathrm{~min}$ and the absorbance was measured at $595 \mathrm{~nm}$.

\section{Histological examination}

The hearts of three animals from each group were removed, washed immediately with saline and then fixed in 10\% buffered formalin. The hearts were embedded in paraffin section cut and stained with hematoxylin and eosin. These sections were then examined under the light microscope for histological changes.

\section{Statistical analysis}

All values are expressed as mean \pm SD for 6 animals in each group. Data for various biochemical parameters were analyzed using one-way analysis of variance followed by Tukey's multiple comparison tests (graph
Pad Version 3.06, La Jolla, CA, USA). Significance is set at $p<0.05$.

\section{RESULTS}

\section{Physicochemical parameters}

After estimation of physical constants the results obtained were total ash $10.33 \% \mathrm{w} / \mathrm{w}$, Acid Insoluble ash $2.12 \% \mathrm{w} / \mathrm{w}$, water soluble ash $5.33 \% \mathrm{w} / \mathrm{w}$, water soluble extractive value $40 \% \mathrm{w} / \mathrm{w}$, Alcohol soluble extractive $72 \% \mathrm{w} / \mathrm{w}$ and moisture content $4.8 \% \mathrm{w} / \mathrm{w}$.

\section{Phytochemical Investigation}

Successful evaluation of botanical phytocompounds from plant material is largely dependent on

The type of solvent used in the extraction procedure. Hence our choice is methanol. The result of phytochemical screen showed the presence of saponinns, Glycosides, Triterpenes, flavonoids, Carbohydrate and steroids leave of Ginkgo biloba (Table 1).

\section{Pharmacological estimation}

The results obtained in the different groups subjected to in-vivo ischemic reperfusion injury are presented below.

\section{Myocardial TBARS}

Myocardial TBARS in GII group (68.65 \pm 1.28$)$ was significantly higher than that in control group (44.82 \pm 1.54$)$. In GIV and GV treated groups there was a significantly lower TBARS $\left(53.76 \pm 2.46^{\mathrm{b}}\right.$ and $\left.44.45 \pm 1.95^{\mathrm{c}}\right)$ respectively, whereas in the GIII group the TBARS shows no significant change $\left(59.25 \pm 1.46^{a}\right)$ in comparison to GII group (Table 2).

\section{Myocardial GSH}

Myocardial GSH level was significantly lower in GII group (217.66 \pm 5.81$)$ in comparison to that of the control group (353.85 \pm 3.69$)$. There was a significant increase in the levels of GSH in the GV (330.4 $\pm 4.83^{c}$ ), whereas in there was slight increase in the levels of GSH levels GIII (304.5 $\left.\pm 7.57^{\mathrm{b}}\right)$ and GIV $\left(312.58 \pm 6.31^{\mathrm{b}}\right)$; in comparison to the GII group (Table 2).

The blood GSH levels of the ISO treated animals showed $(64.33 \pm 1.11)$ a significant decrease $(p<0.01)$ as compared to normal control $(73.16 \pm 1.29)$ group. Here also MEGB at the dose of $500 \mathrm{mg} / \mathrm{kg}$ provided a highly significant $(\mathrm{p}<0.001)$ increase $(71.8 \pm 1.14)$ in blood GSH as compared to Group II, III, IV (Table 3).

\section{Myocardial SOD}

Myocardial SOD activity was significantly lower in GII group $(1.31 \pm 0.16)$ than that in control group (2.91 \pm 0.14$)$. Myocardial SOD levels showed no signifi- 

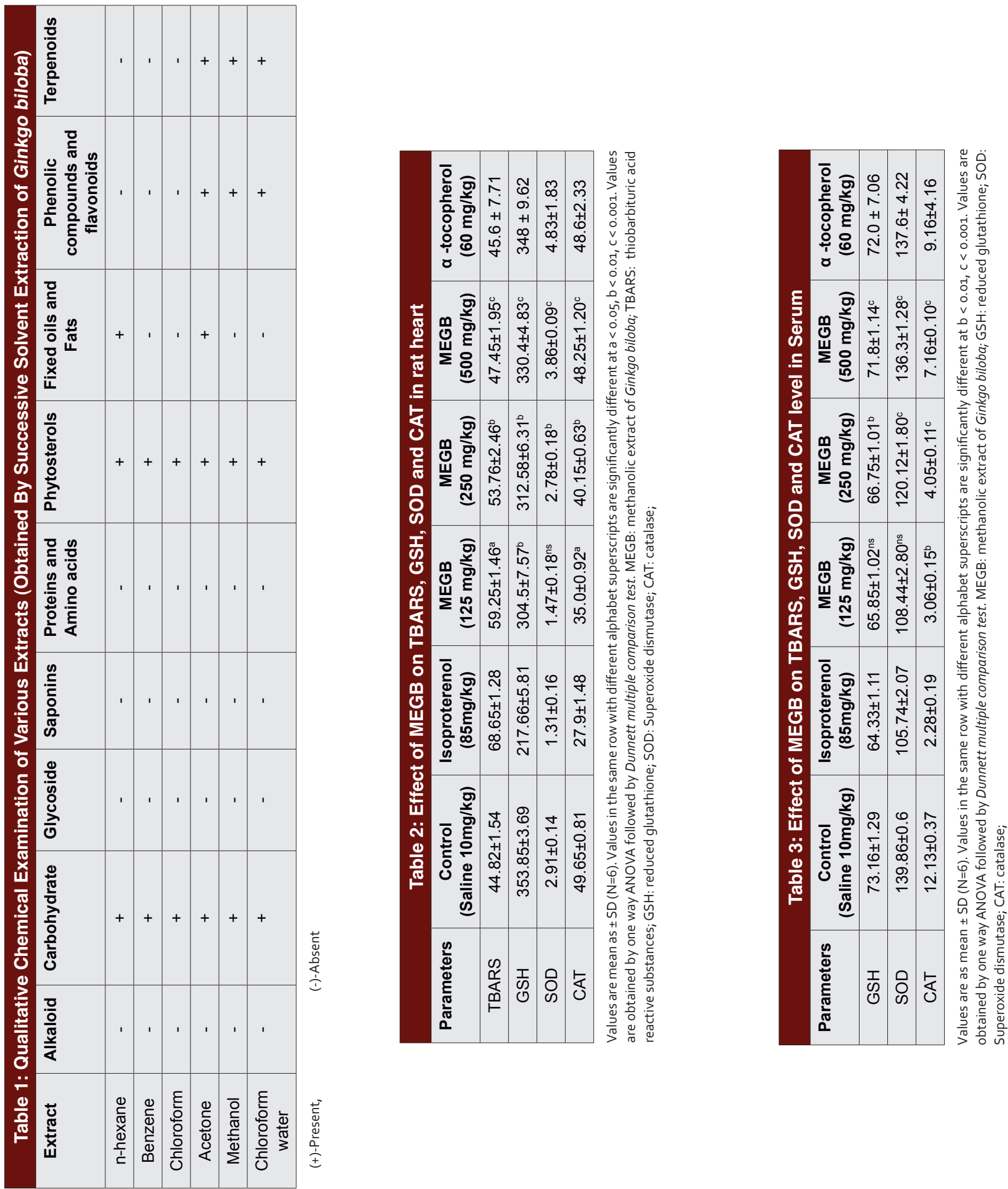
cant change in the GIII groups $\left(1.47 \pm 0.18^{\mathrm{ns}}\right)$ in comparison to GII group. However, the myocardial SOD level was significantly higher in the GIV and GV group $\left(2.78 \pm 0.18^{\mathrm{b}}\right.$ and $3.86 \pm 0.09^{\mathrm{c}}$ respectively) in comparison to GII group (Table 2).

The blood SOD levels of the ISO treated animals showed a significant decrease $(105.74 \pm 2.07)$ as compared to normal control group $(139.86 \pm 0.6)$. Here the dose of MEGB $500 \mathrm{mg} / \mathrm{kg}(120.12 \pm 1.80)$ and $1000 \mathrm{mg} / \mathrm{kg}$ provided a highly significant $(\mathrm{p}<0.001)$ increase $(136.3 \pm 1.28)$ in blood SOD as compared to Group II (Table 3).

\section{Myocardial catalase}

Myocardial catalase was significantly lower in the GII group (27.9 \pm 1.48$)$ in comparison to that of the control group (49.65 \pm 0.81$)$. There was slight increase in myocardial catalase levels in the GIII group $\left(35.0 \pm 0.92^{\mathrm{a}}\right)$ and the GIV group $\left(40.15 \pm 0.63^{b}\right)$ groups, whereas in GV group myocardial catalase was significantly higher $\left(48.25 \pm 1.20^{c}\right)$ in comparison to the control group (Table 2).

The blood CAT level of the ISO treated animals showed a significant decrease $(2.28 \pm 0.19)$ as compared to normal control group (12.13 \pm 0.37 ). MEGB at doses $500 \mathrm{mg} / \mathrm{kg}$ provided a highly significant increase $(4.05 \pm 0.11$ and $7.16 \pm 0.10$ respectively) in blood CAT level as compared to Group II (Table 3).

\section{Histopathological finding}

For histopathological studies three heart samples from each group were extracted and examined under light microscope. The histopathological finding showed the effect of plant Ginkgo biloba on myocardial tissues of the ISO induced rats. Histopathological finding of the vehicle treated rat showed the normal architecture of the myocardium (Figure 1). ISO induced myocardium showed infracted zone with oedema and inflammatory cells and separation of cardiac muscle fibers (Figure 2). Oral pretreatment with Ginkgo biloba $125 \mathrm{mg} / \mathrm{kg}$ showed myocardium with decreased area of infarction with coagulative necrosis and inflammatory cells with moderate oedema (Figure 3). Oral pretreatment with Ginkgo biloba $250 \mathrm{mg} / \mathrm{kg}$ showed myocardium with moderate oedema and inflammatory cells with decreased area of coagulative necrosis of myocardial fibers (Figure 4) and finally treatment Ginkgo biloba $500 \mathrm{mg} / \mathrm{kg}$ showed mild myocardium with mild oedema but no infarction and inflammatory cells and the cardiac fibers were within the normal limits (Figure 5). Rats treated with $\alpha$-tocopherol showed significant protective effect against isoproterenol induce cardiac toxicity and showed normal cyto-architecture of the myocardium (Figure 6). For all the parameters oral pretreatment of Gink.go biloba (125 and $250 \mathrm{mg} / \mathrm{kg}$ ) to ISO induced rats showed a significance improvement in the myocardial infarction and indicates the prophylactic cardio protective effect of Ginkgo biloba (Figure 3 and 4). Group V-VI (500 mg/kg and $\alpha$-tocopherol) showed normal architecture of the heart tissue (Figure 5 and 6).

\section{DISCUSSION}

The effect of ISO on heart is mediated through beta receptors. Both adrenoceptors mediate the positive inotropic and chronotropic effects to beta adrenoceptor agonist. It has been reported to cause severe stress in the myocardium resulting in infarct like necrosis of the heart muscle. ISO-induced myocardial infarction serves as a well-standardized model to study the beneficial effects of many drugs and cardiac function. ${ }^{31}$ It is also well known to generate free radicals and to stimulate lipid peroxidation, which may be a causative factor for irreversible damage to the myocardial membrane. ${ }^{32}$ Extract from the leaves of Ginkgo biloba extract, MEGB, contains flavonoids, saponins, glycoside, steroids, carbohydrate and terpenoids, which are the most important active substances in the extract. The most important flavonoids are glycosides of kaempferol, quercetin, and isorhamnetin with glucose or rhamnose. Ginkgo biloba extract is well known for its antioxidant property, which may result from its ability to scavenge free radicals, and to neutralize ferryl ion-induced peroxidation. ${ }^{33}$ Several studies have reported that the antioxidant activity of Ginkgo biloba extract could be helpful in the prevention and therapy of diseases and degenerative processes associated with oxidative stress. ${ }^{33-37}$ However, there have been very limited studies on the cardio protective activity of Ginkgo biloba extract. It is reasonably hypothesized that Ginkgo biloba extract may be helpful for the therapy of heart failure. Therefore, the purpose of this study was to investigate the cardioprotective effect of Ginkgo biloba methanolic extract in rats. Extensive literature survey has shown that there are no scientific reports available on the effect of MEGB in cardiotoxicity induced by isoproterinol. In our laboratory, we observed the preventive effect of MEGB on cardiac marker enzymes, TBARS, GSH, SOD and CAT in ISO-induced myocardial infarction in rats. . In the present study chronic i.p. administration of Ginkgo biloba leaves extract caused significant rise in myocardial endogenous antioxidants (SOD, GSH and Catalase) in the 250 and $500 \mathrm{mg} / \mathrm{kg}$ treated groups but not with other baseline treated groups. The increase in TBARS is 
indicative of an enhanced oxidative stress, which in the absence of any evidence of cellular injury (as evidenced by histological studies), may be considered as non-lethal. It is, therefore possible that the increase in oxidative stress was nonlethal and might be responsible for cellular adaptive mechanisms. The principal finding of the present study is that cardio toxicity was associated with oxidative stress, as evidenced by increase in myocardial TBARS and depletion of myocardial endogenous antioxidant status (SOD, GSH and Catalase). Similar observations were made earlier by other studies. ${ }^{38-41}$ chronic oral administration of Gingko biloba extract prevents the oxidative stress and the structural changes associated with oxidative stress. The mechanism of such protection of chronic oral administration of Gingko biloba extract may be due to myocardial adaptation, oxidative stress is mediated through augmentation of cellular antioxidants such as GSH, SOD and CAT. Protection against oxidative stress through this mechanism may be one of the effective therapeutic approaches. Histological examination of heart tissue of group 2 rats showed myocardial necrosis and separation of myocardial fibers with inflammatory mononuclear infiltrate whereas the examination of heart tissue of Gingko biloba pretreated group $(500 \mathrm{mg} / \mathrm{kg}$ ) showed maximum protective effect by reduced histological changes as compared to ISO myocardial infracted rats. The protection might have been mediated through extract of Gingko biloba induced increase in basal myocardium antioxidant enzyme activities. Cardio protective effects of MEGB was compared with $\alpha$-tocopherol as the standard natural antioxidant also offered significant protection against ISO-induced depletion of marker enzymes and oxidative stress. This action may be probably due to suppression of membrane damage and reduction in membrane fluidity.

Histopatholoical examination of rat heart-section treated with MEGB and $\alpha$-tocopherol restored the myocardial damage with no evidence of focal damage produced by isoproterenol, which showed the cytoprotective action of MEGB.

Administration of antioxidant-rich natural drugs decreases the mortality from cardiovascular diseases and also promises a therapeutic approach to combat oxidative stress associated with cardiac diseases. As per phytochemical investigation, the MEGB contain flavonoids and phenolic compounds in high concentrations, which might be a responsible active principle for the cardio protective action.

\section{CONCLUSION}

In this respect, the present study showed for the first time that the leaves of Ginkgo biloba are particularly useful agents, as they could enhance myocardial and blood endogenous antioxidants level without producing any cytotoxic effects. Therefore, the protection against myocardial injury in the treated rats is attributed to enhanced endogenous antioxidant activity. So I concluded that this study of Ginkgo biloba can help for further research area for ayurveda in cardiovascular and another disease which caused due to oxidative stress.

\section{ACKNOWLEDGEMENT}

The authors are highly thankful to management, GRY Institute of Pharmacy to provide the facilities to carry out the research work. Thanks are due to Dr. S. K. Mahajan, Botanist at Govt. PG Collage, Khargone-451001 for authentication of plant.

\section{ABBREVIATION USED}

ISO: Isoproterenol; MEGB: methanolic extract of Ginkgo biloba; CPCSEA: Committee for the Purpose of Control and Supervision of Experimental on Animals; TBARS: thiobarbituric acid reactive substances; TCA: Trichloroacetic acid; GSH: reduced glutathione; SOD: Superoxide dismutase; CAT: catalase; NADH: nicotinamide adenine dinuclotide

\section{REFERENCES}

1. Boudina S, Lactau MN, Tariosse L, Daret D, Gouverneur G, Bonoron-Adele $\mathrm{S}$, et al. Alteration of mitochondrial function in a model of chronic ischemia in vivo in rat heart. Am J Physiol Heart Circ Physiol. 2002;282:821-32.

2. Das DK, Maulik N. Protection against free radical injury in the heart and cardiac performance. Elsevier Science, Amsterdam. 1995; 359-388.

3. Vaage J, Valen G. Pathophysiology and mediatore of ischemiareperfusion injiry with special reference to cardiac surgery. Scand J Thorac Cardiovasc Surg. 1993; 41: 1-18.

4. Karthikeyan K, Bai BRS, Devaraj SN. Grape seed proanthocyanidins ameliorates Isoproterenol-induced myocardial injury in rats by stabilizing mitochondrial and lysosomal enzymes: an in vivo study. Life sci 2007; 81 : 1615-1621.

5. Chagoya SV, Hernandez-munoz R, Lopez-Barrera F, Yanez L, Vidrio S, Suarez J. Sequential changes of energy metabolism and mitochondrial function myocardial infarction induced by Isoproterenol in rats: a long-term and integrative study. Can J Physiol Pharmacol. 1997; 75: 1300-1311.

6. Senthil S, Sridevi M, Pugalendi KV. Cardioprotective effect of oleanolic acid on isoproterenol-induced myocardial ischemia in rats. Toxicol Pathol.2007; 35:418-423.

7. Das L, Bhaumik E, Raychaudhuri U, Chakraborty R. Role of nutraceuticals in human health. J Food Sci Technol. 2012; 49:173-183.

8. Visweswaran P, Massin EK, Dubose TD. Mannitol induced acute renal failure. J Am Soc Nephrol. 1997; 8:1028-1033.

9. Banerjee SK, Dinda AK, Manchanda SC, Maulik SK. Chronic garlic administration protects rat heart against oxidative stress induced by ischemic reperfusion injury. BMC Pharmacol. 2002; 2:16.

10. Jocobs BP, Browner WS. Ginkgo biloba: A Living fossil. American Journal of Medicine 2000; 108:341-2. 
11. Solomon PR, Adams F, Silver A, Zimmer J, DeVeaux R: Ginkgo for Memory Enhancement: A Randomized Controlled Trial: JAMA 2002; 288:835-40.

12. Junji T, Hiroyuki S, Kaori I, Oliver G, Shujiro S, Veronika B, et al. Antidepressant effect of extracts from Ginkgo biloba leaves in Behavioral models. Biol Pharm Bull. 2006; 29(8): 1767-1770.

13. Naik S, Panda V. Antioxidant and Hepatoprotective effects of Ginkgo biloba phytosomes in carbon tetrachloride-induced liver injury in rodents. Liver International. 2007; 27(3): 393-399.

14. Itokawa H, Totsuka N, Nakahara K, Maezuru M, Takeya K, Kondo M, et al. A quantitative structure activity relationship for antitumor activity of long chain phenols from Ginkgo biloba. Chem. Pharm. Bull. 1989; 37:1619-1621.

15. Rai GS, Shovlin C, Wesnes KA. A double blind, placebo controlled study of Ginkgo biloba extract ("takanan") in elderly outpatients with mild to moderate memory impairment. Curr. Med. Res. Opin. 1991; 12:350-355.

16. Chen SH, Liang YC, Chao J, Tsai LH, Chang CC, Wang CC, et al. "Protective effects of Ginkgo biloba extract on the ethanol-induced gastric ulcer in rats" World Journal of Gastroenterology. 2005 June 28; 11(24):3746-3750.

17. Jain SP, Tekade AR, Joshi UM, Kale RH, Purohit RN. Protective effect of Ginkgo biloba on Antitubercular drugs induced Hapetotoxicity in rats. Indian drugs. 2005; 42(3); 167-170.

18. Ya-bin JIAO, Yao-cheng RUI, Tie-jun LI, Peng-yuan YANG, Yan QIU, Expression of pro-inflammatory and anti-inflammatory cytokines in brain of atherosclerotic rats and effects of Ginkgo biloba extract, Acta Pharmacologica Sinica. $2005 \mathrm{Jul} ; 26$ (7): 835-839.

19. Satomi KAGOTA, Yukari TADA, Yoko KUBOTA, Namie NEJIME, Kazuki NAKAMURA, Masaru KUNITOMO, Kazumasa SHINOZUKA, et al. LongTerm Feeding of Ginkgo biloba Extract Impairs Peripheral Circulation and Hepatic Function in Aged Spontaneously Hypertensive Rats, Biol. Pharm. Bull. 2008; 31(1): 68-72.

20. Shang-Zhen Huang, Yan-Jun Luo, Li Wang, Ke-Yin Cai, Effect of Ginkgo biloba extract on livers in aged rats, World J Gastroenterol. 2005;11(1):132-135.

21. CHIARA ATZORI, ANTONELLA BRUNO, GUIDO CHICHINO, EZIO BOMBARDELLI, MASSIMO SCAGLIA,' MARIO GHIONE, et al., Activity of Bilobalide, a Sesquiterpene from Ginkgo biloba, on Pneumocystis carinii. ANTIMICROBIALAGENTS AND CHEMOTHERAPY, 1993; 37 (7): P. 1492-1496.

22. Rai D, Bhatia G, Sen T, Palit G. Anti-stress Effects of Ginkgo biloba and Panax ginseng: a Comparative Study. Journal of Pharmacological science. 2003; 93: 458-464.

23. Droy-Lefaix MD. Effect of the antioxidant action of Ginkgo biloba extract (EGB 761) on aging and oxidative stress. Age. 1997; 20: 141-149.

24. Shah CS, Quadry JS. A Text Book of Pharmacognosy. $11^{\text {th }}$ ed. Ahmedabad: BS Shah Prakashan; 1996; 8-13.

25. Kokate CK., Purohit AP., Gokhale SB., A Text Book of Pharmacognosy. $50^{\text {th }}$ ed. Nirali Prakashan; 2014; 7.15-7.25.

26. Gauthaman K, Saleem TS, Thanislas PT, Prabhu VV, Krishnamoorthy KK, Devaraj NS, et al. Cardioprotective effect of the Hibiscus rosa sinensis flowers in an oxidative stress model of myocardial ischemic reperfusion injury in rat. BMC Complementary and Alternative Medicine. 2006; 6:32.
27. Okhawa H, Qohishi N, Yagi K. Assay of lipid peroxides in animal tissues by thiobarbituric acid reaction. Anal Biochem. 1979; 95:351-358.

28. Ellman GL. Tissue Sulphydryl groups. Archives Biochem \& Biophysics. 1959; 82:70-77.

29. Kakkar P, Das B, Viswanatham PN. A modified spectrophotometric assay of superoxide dismutase. Indian Journal of Biochem \& Biophysics. 1984; 21:130-132.

30. Aebi H. Catalase In: Methods of enzymatic analysis. Ed. By Bergmeyer HU. Chemic Academic Press Inc Verlag. 1974; 2:673-685.

31. Bradford MM. A rapid and sensitive method for the quantitation of microgram quantities of protein utilizing the principle of protein-dye binding. Analytical Biochemistry. 1976; 7(72):248-254.

32. Ithayarasi AP, Devi CSS. Effect of alpha tocopherol on lipid peroxidation in isoproterenol induced myocardial infarction in rats. Indian $\mathrm{J}$ Physiol Pharmacol. 1997; 41:369-76.

33. Kakreja RC, Hess ML. The oxygen free radical system from equations through membrane protein interactions to cardiovascular injury and protection. Cardiovasc Res. 1992; 26:641-55.

34. Deby C, Deby-Dupont G, Dister M, Pincemail J. Efficiency of Ginkgo biloba Extract (EGb 761) in neutralizing ferryl ion-induced peroxidations: therapeutic implication. In: Ferradini C, Droy- Lefaix MT, Christen Y, eds. Advances in Ginkgo biloba extract research: Ginkgo biloba extract (EGb 761) as a freeradical scavenger. New York: Elsevier Science. 1993; 13-26.

35. Sram RJ, Binková B, Stejskalová J, Topinka J. Effect of EGb 761 on lipid peroxidation, DNA repair and antioxienzyme activity. In: Ferradini C, DroyLefaix MT, Christen Y, eds. Advances in Ginkgo biloba extract research: Ginkgo biloba extract (EGb 761) as a free-radical scavenger. New York: Elsevier Science. 1993: 27-38.

36. Szabo ME, Droy-Lefaix MT, Doly M. Reduction of reperfusion induced ionic imbalance by superoxide dismutase, vitamin E and Ginkgo biloba extract 761 in spontaneously hypertensive rat retina. In: Ferradini C, Droy-Lefaix MT, Christen Y, eds. Advances in Ginkgo biloba extract research: Ginkgo biloba extract (EGb 761) as a free-radical scavenger. New York: Elsevier Science. 1993: 93-106.

37. Oken BS, Storzbach DM, Kaye JA. The efficacy of Ginkgo biloba extract on cognitive function in Alzheimer disease. Arch Neurol. 1998; 55: 1409-1415.

38. Onen A, Deveci E, Inaloz SS, Isik B, Kilinc M. Histopathological assessment of the prophylactic effect of Ginkgo biloba extract on intestinal ischemiareperfusion injury. Acta Gastroenterol Belg. 1999; 62: 386-389.

39. Yim MB, Chock PB, Stadtman ER. Copper, Zinc, superoxide dismutase, catalyses hydroxyl radical production from hydrogen peroxide. National Academic Science USA. 1990; 87(13):5006-5010.

40. Singal PK, Dhalla AK, Hill M, Thomas TP: Endogenous antioxidant changes in the myocardium in response to acute and chronic stress conditions. Molecular Cell Biochemistry. 1993; 129:179-186.

41. Seth SD, Maulik M, Katiyar CK, Maulik SK. Role of lipistat in protection against isoproterenol induced myocardial necrosis in rats, a biochemical and histopathological study. Indian Journal of Pharmacology. 1998; 42(1):101-106.

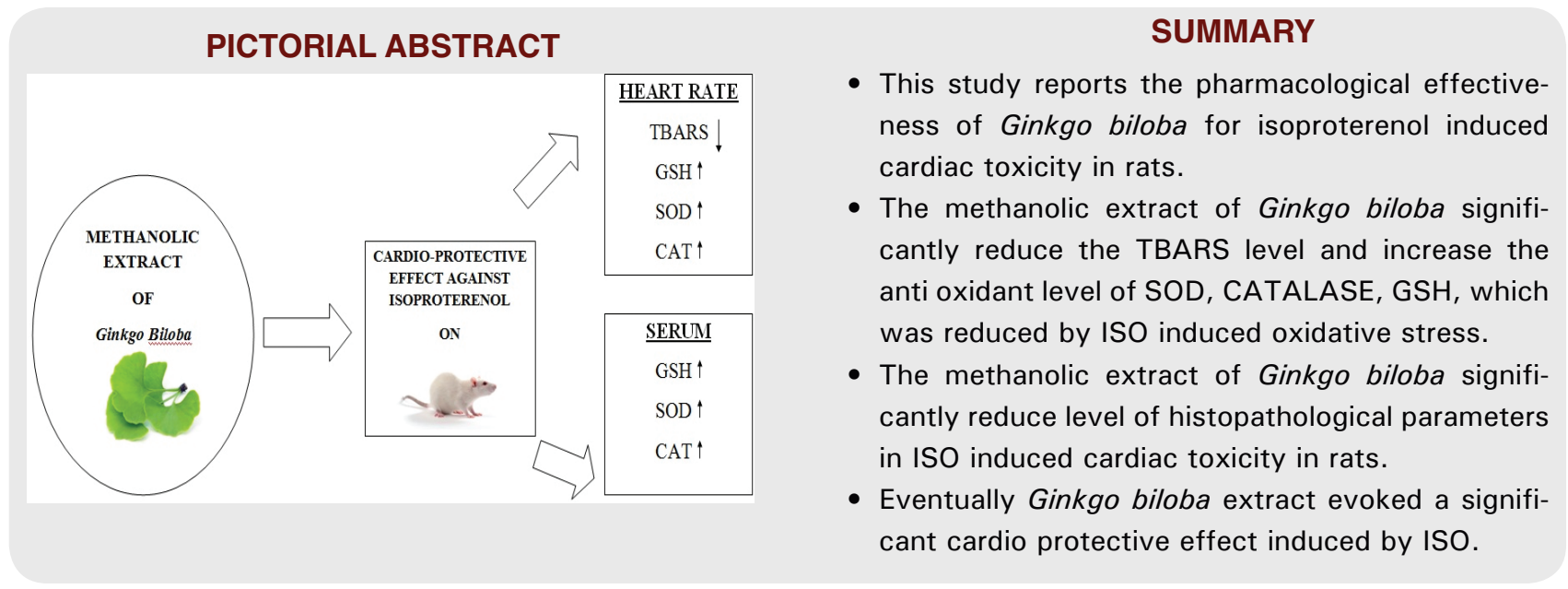




\section{About Authors}

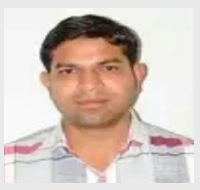

Mr. Narendra singh Badore: presently working as associate Professor in pharmacognosy division at GRY Institute of Pharmacy, Borawan, Khargone, MP. He is engaged in teaching and research since last eight years. He published many research publications in various national and international journals.

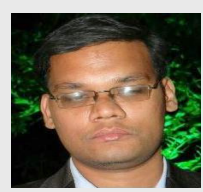

Mr. Prabhat Kumar Das: presently working as associate Professor in pharmacology division at GRY Institute of Pharmacy, Borawan, Khargone, MP. Mr. Das is engaged in teaching and research since last nine years. He keeps his research interest in various biological activities i.e. hepato-protective, anti ulcer, anti diabetic, anti inflammatory etc. He published 20 research articles in various national and international journals and participates in many national and international conferences, workshop seminars in his carrier.

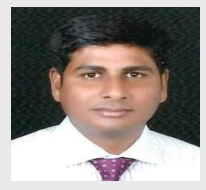

Dr. Sujit Pillai: Currently working as Principal and HOD of pharmaceutical chemistry dept at GRY Institute of pharmacy, Borawan, MP. He has fifteen years of teaching and research experience in various institutes. He also has the professional membership of APTI. He published many research publications in various national and international publications.

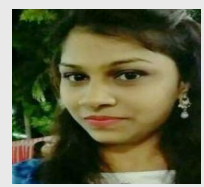

Miss Akshita Thakur: Is brilliant scholar of final year B. Pharma at GRY institute of Pharmacy. She has the excellent overall percentage in her B. Pharma carrier. She participated in various research activities conducted in pharmacognosy as well as pharmacology division in the institute.

Cite this article: Badore NS. Role of Ginkgo biloba Extract, Against Isoproterenol Induced Cardiac Toxicity in Rats. Indian J of Pharmaceutical Education and Research. 2017;51(4S):S691-S9. 